\section{崊图 Digital Commons@}

Loyola Marymount University

LMU Loyola Law School
Loyola of Los Angeles Entertainment Law Review

Volume 39 | Number 3

Article 3

Spring 5-11-2019

\title{
Taxation in the Cyber Age: The Future of Wayfair
}

Hasmik Hmayakyan

LMU Loyola Law School, Los Angeles, hasmik.hmayakyan@lls.edu

Follow this and additional works at: https://digitalcommons.Imu.edu/elr

Part of the Entertainment, Arts, and Sports Law Commons, and the Tax Law Commons

\section{Recommended Citation}

Hasmik Hmayakyan, Taxation in the Cyber Age: The Future of Wayfair, 39 Loy. L.A. Ent. L. Rev. 285 (2019).

Available at: https://digitalcommons.Imu.edu/elr/vol39/iss3/3

This Notes and Comments is brought to you for free and open access by the Law Reviews at Digital Commons @ Loyola Marymount University and Loyola Law School. It has been accepted for inclusion in Loyola of Los Angeles Entertainment Law Review by an authorized administrator of Digital Commons@Loyola Marymount University and Loyola Law School. For more information, please contact digitalcommons@lmu.edu. 


\section{TAXATION IN THE CYBER AGE: THE FUTURE OF WAYFAIR}

\section{Hasmik Hmayakyan*}

This Comment aims to act as a guiding source for potential issues that will arise from South Dakota v. Wayfair, which was decided in August 2018. The Wayfair decision changed the long-held requirement that states can only collect sales taxes from sellers that have a physical presence within the state.

Under Complete Auto Transit, Inc. v. Brady, the Supreme Court put forth a test that states must meet if they wish to collect a sales tax from sellers. One of the prongs of this test allows a state to collect a sales tax from a seller if the seller has created a substantial nexus within the state. Under Quill Corp. v. North Dakota, a substantial nexus was defined as a physical presence. This physical presence requirement meant out-of-state sellers, such as online retailers, were not required to pay a sales tax to states where they sold their products, since these sellers did not have a physical presence within the state.

For years, states attempted to circumvent the physical presence requirement under Quill but were unable to do so successfully. In August 2018, the Supreme Court in South Dakota v. Wayfair held that a seller does not need a physical presence within a state in order for a state to require the seller to pay a sales tax. The Court considered three factors: (1) South Dakota's substantial nexus requirement, which stated an out-of-state seller creates a nexus with South Dakota if they have made at least $\$ 100,000$ in sales or 200 transactions with consumers in South Dakota; (2) South Dakota is part of the Streamlined Sales and Use Tax Agreement (SSUTA), which streamlines the process of sales tax collection; and (3) the Court's decision would not apply retroactively to past transactions.

The Court's opinion applied specifically to the laws in place in South Dakota. Since the opinion in Wayfair was specific to South Dakota, states started enacting their own legislation similar to South Dakota's so that they can start charging a sales tax on out-of-state sellers as well.

${ }^{*}$ J.D. Candidate 2020, Loyola Law School, Los Angeles. The author would like to thank Professor Theodore Seto for his assistance in publishing this Comment; Nairi Dulgarian for being her support system; and, her family for their love and encouragement. 
Congress can remain silent on the issue in order to allow the states to continue to act as they deem fit. Alternatively, since each state has set its own requirements, Congress can step in and set a uniform system of requirements for states to meet in order to collect sales taxes. Congress has the constitutional authority to act under the Commerce Clause to create a uniform system of taxation. A uniform system will provide states and sellers with guidance on how to proceed in light of the Wayfair decision.

This Comment argues that Congress should enact a statute to create a uniform system of taxation. The uniform system will include a definition of what constitutes a good (products purchased from online retailers) and what constitutes a service (online streaming services). Additionally, the uniform system will create a minimum substantial nexus requirement, preferably by adopting the requirement that South Dakota has in place. The uniform system will also require states who wish to collect a sales tax from online sales to be members of the Streamlined Sales and Use Tax Agreement (SSUTA). Lastly, the uniform system will forbid states from applying the Wayfair decision retroactively. 
"There was a time when people felt the internet was another world, but now people realize it's a tool that we use in this world." - Sir Tim Berners-Lee, $2003^{1}$

\section{INTRODUCTION}

Amazon revolutionized the world of retail because it made shopping for everyday items quicker, easier, and more accessible. ${ }^{2}$ With one click, a consumer can have almost anything they need at their doorstep within days, if not hours. Consumers also have immediate access to music, videos, and books through Amazon. ${ }^{3}$ Rather than purchasing a CD, DVD, or book and waiting for it to arrive, consumers can purchase a song, a movie, or a book and have immediate access to it online. ${ }^{4}$ Not only does Amazon provide a seemingly unlimited inventory of items, but Amazon also did not charge a state sales tax on the items it sold. ${ }^{5}$ This meant a consumer could purchase an item online and not be required to pay a sales tax on the item. Sounds like a steal, doesn't it? Most states would agree. ${ }^{6}$

Under Quill Corp. v. North Dakota, ${ }^{7}$ states were unable to enforce a state sales tax on sellers who did not have a physical presence within the state. ${ }^{8}$ States were frustrated with the fact that they were unable to collect

1. Knighthood for 'father of the Web', CNN (Dec. 31, 2003, 11:08 AM), http://www.cnn.com/2003/WORLD/europe/12/31/britain.honors.webman/ [https://perma.cc/YQM6-E3FS].

2. See generally Susan Reda, 21 Ways Amazon Changed the Face of Retail, NATIONAL RETAIL FEDERATION (Sep. 12, 2016), https://nrf.com/blog/21-ways-amazon-changed-the-face-ofretail [https://perma.cc/P79A-WA3K].

3. See generally Adam Epstein, How to Gift Entertainment in the Age of the Internet, QUARTZY (Dec. 15, 2017), https://qz.com/quartzy/1125287/how-to-gift-entertainment-in-the-ageof-the-internet/ [https://perma.cc/A3W5-Q5HA].

4. Id.

5. Chris Isidore, Amazon to Start Collecting State Sales Taxes Everywhere, CNN BUSINESS (March 29, 2017, 2:59 PM), https://money.cnn.com/2017/03/29/technology/amazon-sales-tax/index.html [https://perma.cc/YLR5-3572].

6. See Donald Bruce \& William F. Fox, E-Commerce in the Context of Declining States Sales Tax Bases, 53 NAT'L TAX J. 1373, 1374-76 (2000).

7. Quill Corp. v. North Dakota, 504 U.S. 298, 301 (1992).

8. Under Quill, "[t]he court's limitation of collection responsibility to firms with physical presence was based on the Commerce Clause, meaning that Congress has the authority to override 
sales taxes from out-of-state sellers. ${ }^{9}$ The Quill standard created a loophole in the law that favored out-of-state sellers because they were not held liable for collecting and remitting state sales taxes. Due to the increase of online shopping and the loophole created by Quill, many states experienced a decline in sales tax revenue. ${ }^{10}$

In June 2018, the Court in South Dakota v. Wayfair, Inc. tackled the issue of whether it is constitutional for states to collect a sales tax from sellers that conduct business within the state, but do not have a physical presence within the state. ${ }^{11}$ The Wayfair decision overruled Quill and allowed for South Dakota to collect a state sales tax from Wayfair's sales within South Dakota, even though Wayfair had no physical presence within South Dakota. $^{12}$

The Wayfair decision is specific to South Dakota. ${ }^{13}$ The Court in Wayfair determined that the laws in South Dakota that surround the issue are not unconstitutional, so South Dakota may collect a sales tax from the sales Wayfair made in South Dakota. ${ }^{14}$ These requirements are specific to South

the decision through legislation." Bruce \& Fox, supra note 6, at 1375. A seller has physical presence within a state if the seller has operations physically located within the state. Physical operations include offices, stores, warehouses, property, and employees. Jennifer Jensen, States Probing Boundaries of 'Physical Presence', THE TAX ADVISER (Oct. 1, 2017), https://www.thetaxadviser.com/issues/2017/oct/states-probing-boundaries-physical-presence.html [https://perma.cc/M475-F445].

9. Carl Davis, Amazon Will Collect Every State Sales Tax by April 1, InSTITUTE ON TAXATION AND ECONOMIC POLICY: Just TAXES Blog (Mar. 21, 2017), https://itep.org/amazonwill-collect-every-state-sales-tax-by-april-1/ [https://perma.cc/D97M-HNVM].

10. Bruce \& Fox, supra note 6, at 1374-6.

11. South Dakota v. Wayfair, Inc., 138 S. Ct. 2080, 2088 (2018).

12. Wayfair, 138. S. Ct. at 2099.

13. Id. The Court in Wayfair explained that the law in South Dakota is not unconstitutional because "[f]irst, the Act applies a safe harbor to those who transact only limited business in South Dakota. Second, the Act ensures that no obligation to remit the sales tax may be applied retroactively. S.B. 106, § 5. Third, South Dakota is one of more than 20 States that have adopted the Streamlined Sales and Use Tax Agreement."

14. See id. 
Dakota and, accordingly ${ }^{15}$ if other states attempt to apply the Wayfair decision to their own states, potential issues may arise.

Wayfair also paved the way for Congress to act and change the requirements for states to collect taxes from out-of-state sellers. ${ }^{16}$ So far, Congress has not passed legislation in regard to the Wayfair case, but some states have acted toward the adoption of a system of taxation for out-of-state sellers. ${ }^{17}$ Congress can either continue not to act and leave the taxation of out-of-state sellers to the states, or Congress can enact legislation that codifies the requirements of Wayfair. Leaving taxation to the states is favorable for states because it allows the states to do what is best for their own state. However, this option is not favorable for sellers because it would require sellers to keep up with various sales tax laws passed by each state.

The better option for Congress is to codify Wayfair. In order to collect sales taxes from out-of-state sellers, states should be required to implement the taxation requirements set forth by South Dakota in order to avoid issues of constitutionality. However, states have a general desire to be autonomous and implement their own tax laws, especially states with more complex forms of taxation that would find it difficult to conform to a uniform set of requirements. Despite states' desire for autonomy, codifying Wayfair is favorable for out-of-state sellers because this option would create uniformity amongst states that collect a state sales tax from out-of-state sellers, which would in turn reduce confusion for out-of-state sellers. A uniform requirement would also be beneficial to states because it would provide states with guidance as to how to proceed after the Wayfair decision. Thus, Congress should act and codify Wayfair in order to impose a uniform system of taxation for transactions between out-of-state sellers and in-state consumers.

Part II of this Article provides a brief overview of taxation and analyzes the history of state sales taxation leading up to an exploration of the Wayfair decision, describes actions states have taken since the decision, and discusses whether Congress has the Constitutional authority to take action on the mat-

15. See Jeffrey S. Reed, A Range of State Responses After Wayfair, LEXOLOGY (Sept. 27, 2018), https://www.lexology.com/library/detail.aspx?g=4d5d0ac9-e17c-489e-a161-8cfb51e236ea [https://perma.cc/4K97-PBHX].

16. Wayfair, 138 S. Ct. at 2098.

17. See Robert Verbruggen, The Supreme Court Just Gave States Power to Tax Online Sales, NATIONAL REVIEW (June 22, 2018, 2:13 PM), https://www.nationalreview.com/2018/06/online-sales-tax-supreme-court-ruling-make-congress-act/ [https://perma.cc/4FJH-Z7QH]; Reed, supra note 15. 
ter. Part III of this Article lays out the options available to Congress, including the option to remain silent and let the states act on their own, the option to adopt uniform terminology for the taxation of goods and services, and the option to codify Wayfair by setting a uniform nexus requirement, requiring membership in the Streamlined Sales and Use Tax Agreement (SSUTA), and forbidding retroactive application of the decision. Finally, this Article concludes that Congress should codify Wayfair in order to promote small businesses to continue to sell their products between states. Accordingly, this Article aims to act as a guiding source for potential issues that will arise from the Wayfair decision.

\section{BACKGROUND}

\section{A. Sales and Use Taxes Explained}

A sales tax is a tax that is levied on the sale of a good or service, both of which are defined below. ${ }^{18}$ Sales taxes are imposed and collected by states, not the federal government. ${ }^{19}$ When a consumer purchases a product from a seller, the consumer pays a sales tax to the seller. ${ }^{20}$ The seller then pays this tax to the state, a process that is known as remittance. ${ }^{21}$ In order to remit the sales tax to the state, the seller registers for a permit with the state tax organization - an organization that is responsible for the collection of state taxes. $^{22}$ The seller then files a report of how much sales tax was collected, along with a sales tax return.

18. See Resource Center, U.S. DePARTMEnT OF THE TREASURy (Feb. 17, 2019), https://www.treasury.gov/resource-center/faqs/Taxes/Pages/economics.aspx

[https://perma.cc/84EH-2LLC].

19. Id.

20. The Seller's Guide to eCommerce Sales Tax, TAXJAR (Dec. 14, 2018), https://www.taxjar.com/guides/intro-to-sales-tax/\#what-is-sales-tax [https://perma.cc/4NJ25MT3].

21. Id.

22. TaxJar, What is Sales Tax?, YouTuBE (Dec. 29, 2017), https://www.youtube.com/watch?v=5gPKryXgJgg\&index=1\&list=PLYtbVC9ZFw4XYBdkWchEU-cX_ys_1VGO [https://perma.cc/5E7S-WEAC]. 
A use tax, on the other hand, is a tax that is applied to a product if an out-of-state seller did not collect a sales tax on the product. ${ }^{23}$ Instead of the seller remitting a sales tax to the state, the consumer remits a use tax to the state on the product they purchased..$^{24}$

The costs associated with the collection and remittance of sales and use taxes are known as compliance costs. ${ }^{25}$ Compliance costs are generally the responsibility of the seller because the seller needs to comply with state tax laws. These costs include registering for a sales tax permit, maintaining software to track the collection of sales taxes from consumers, maintaining software to remit sales taxes to the state, filing corporate tax returns, filing annual reports, and filing reports about workers compensation with the state. ${ }^{26}$

Sales taxes are collected on goods. Goods used for tax purposes are called tangible personal property (TPP). In most states, TPP is defined as "property that can be touched or moved, which broadly encompasses both personal use property and property held for business or production of income." 27 Other states have a narrower definition of TPP. In these states, TPP is defined as "property that is held or used for business or production of income." 28

Some states also collect a sales tax on services. ${ }^{29}$ These states have divided services into multiple categories, each with its own definition and

23. Marc Lifsher et al., State to Target Web Retailers for Sales Taxes, Los ANGELES TIMES (Aug. 31, 2012), http://articles.latimes.com/2012/aug/31/business/la-fi-0831-internet-taxes-crackdown-20120831 [https://perma.cc/ZY8E-ZXBT].

24. Id.

25. See Laurence Kotlikoff, Did The Supreme Court Potentially Bankrupt Tens of Thousands of Small Online Businesses?, FORBES (June 21, 2018, 3:14 PM), https://www.forbes.com/sites/kotlikoff/2018/06/21/did-the-supreme-court-just-bankrupt-tens-ofthousands-of-small-online-businesses/\#4ef1da9427aa [https://perma.cc/H2AG-T8KF].

26. $I d$.

27. Joyce Errecart et al., States Moving Away From Taxes on Tangible Personal Property, TAX FOUNDATION 1, 1 (Oct. 2012), https://files.taxfoundation.org/legacy/docs/bp63.pdf [https://perma.cc/C2DY-F6CK].

28. $I d$.

29. Sales Tax on Services by State, AVALARA, https://www.avalara.com/us/en/learn/whitepapers/service-taxability-by-state.html [https://perma.cc/Y3WY-QAAE]. 
examples. ${ }^{30}$ States do not tax within every category of services, and tax regulations will likely vary from state to state for each category. ${ }^{31}$ Each state has its own regulations under the categories of services, so if a service is exempt from tax in one state, it does not necessarily mean the service is exempt from tax in a different state.

\section{B. The Four-Part Test from Complete Auto Transit, Inc. v. Brady ${ }^{32}$}

If a state intends to collect a sales tax from out-of-state sellers, the state must follow the four-part test set forth by the Court in Complete Auto Transit, Inc. v. Brady. In Complete Auto, the Court introduced a four-part test to determine if it is constitutional for a state to impose a tax on a seller. ${ }^{33}$ In order for a state to collect a sales tax from a seller, the tax must be "[1] applied to an activity with a substantial nexus within the taxing State, [2] fairly apportioned, [3] does not discriminate against interstate commerce, and [4] fairly related to the services provided by the State." 34 If all elements of this test are met, a state can collect a sales tax without interfering with Congress's authority to regulate commerce between states. ${ }^{35}$

The first prong allows a state to collect sales tax from a seller when the seller has created a substantial nexus with the state. ${ }^{36}$ The second prong of the test requires the sales tax imposed by a state to be fairly apportioned. ${ }^{37}$ In Goldberg v. Sweet, the Court defined a "fairly apportioned" tax as one that is "internally and externally consistent." 38 A tax is internally consistent if it is structured in a way "such that if every state were to impose an identical

30. Id.

31. Id.

32. Complete Auto Transit, Inc. v. Brady, 430 U.S. 274, 279 (1997).

33. Id.

34. Id.

35. See U.S. CONST. art. I, $\S 8$, cl. 3 .

36. Complete Auto Transit, Inc., 430 U.S. at 279.

37. Id.

38. Goldberg v. Sweet, 488 U.S. 252, 261 (1989). 
tax, no multiple taxation would result." ${ }^{39}$ A tax is externally consistent when the tax is proportional to the amount of business conducted within the state by the seller. ${ }^{40}$ The third prong of the test ensures a transaction or incident will not be taxed more heavily if it occurs across state lines as opposed to within the State. ${ }^{41}$ Lastly, the fourth prong of the test requires the tax to be related to the earnings that a seller made from a certain state. ${ }^{42}$

\section{Historical Developments of the Substantial Nexus Prong}

\section{Judicial Developments}

The Wayfair decision only affects the first prong of the Complete Auto test, so this article will focus on the first prong. The first prong of the test set forth in Complete Auto is the substantial nexus prong, which requires a substantial nexus to be created by the seller within the taxing state before state sales taxes can be imposed on the seller. ${ }^{43}$

In Quill, the Court defined "substantial nexus" to mean physical presence. ${ }^{44}$ According to the majority opinion, a state can impose a sales tax on a seller who has a physical presence within the state, such as operations physically located in the state. ${ }^{45}$ For example, offices, stores, warehouses, property, and employees within the state would fulfill the physical presence requirement. ${ }^{46}$ On the other hand, if the only contacts a seller has with the taxing state is through mail or a common carrier, then the seller does not

39. Id.

40. Id.

41. Complete Auto Transit, Inc., 430 U.S. at 279.

42. Commonwealth Edison Co. v. Montana, 453 U.S. 609, 617 (1981).

43. Complete Auto Transit, Inc., 430 U.S. at 279.

44. Quill Corp. v. North Dakota, 504 U.S. 298, 313-14 (1992).

45. Id. at 306 .

46. Jennifer Jensen, States Probing Boundaries of 'Physical Presence', THE TAX ADVISER (Oct. 1, 2017), https://www.thetaxadviser.com/issues/2017/oct/states-probing-boundaries-physical-presence.html [https://perma.cc/M475-F445]. 
meet the substantial nexus requirement to be taxed by the state. ${ }^{47}$ The shipment of goods into a state is also not enough to satisfy the "physical presence" requirement. ${ }^{48}$

Under Quill, states could not require sellers without a physical presence in the state to collect and remit sales taxes, but states could still require consumers to pay a use tax on the products they purchased. ${ }^{49}$ However, few consumers complied with this law and states had difficulty with its enforcement. ${ }^{50}$

\section{State Actions}

Quill was decided in 1992, which was well before online transactions were as popular as they are today. ${ }^{51}$ The prevalence of online transactions negatively affected brick-and-mortar stores, such as bookstores, video stores, and record stores. For example, in the 1990s, the book industry's primary concern was that large chains like Barnes \& Noble and Borders would take business from independent bookstores. ${ }^{52}$ The World Wide Web had only become available to the public in 1991 and Amazon launched in 1995 as an online bookstore. ${ }^{53}$ Over the years, however, Amazon's market share in the book industry increased, and as of March 2014, Amazon held a 41 percent

47. Nat'l Bellas Hess, Inc. v. Dep't of Revenue of State of Ill., 386 U.S. 753, 757 (1967).

48. See Nat'l Bellas Hess, Inc., 386 U.S. 753.

49. Marc Lifsher et al., State to Target Web Retailers for Sales Taxes, Los ANGELES TIMES (Aug. 31, 2012), http://articles.latimes.com/2012/aug/31/business/la-fi-0831-internet-taxes-crackdown-20120831 [https://perma.cc/ZY8E-ZXBT].

50. Id.

51. Quill Corp., 504 U.S. at 298.

52. Benny Evangelista, How 'Amazon factor' Killed Retailers like Borders, Circuit City, SF GATE (July 14, 2015, 3:21 PM), https://www.sfgate.com/business/article/How-Amazon-factorkilled-retailers-like-6378619.php [http://archive.today/gF1cY].

53. Martin Bryant, 20 Years Ago Today, the World Wide Web Opened to the Public, THE NeXT Web (Aug. 6, 2011), https://thenextweb.com/insider/2011/08/06/20-years-ago-today-theworld-wide-web-opened-to-the-public [https://perma.cc/9VDY-5J45]; Caroline Cakebread, Amazon Launched 22 Years Ago This Week - Here's What Shopping on Amazon Was Like Back in 1995, BUSINESS INSIDER (July 20, 2017, 9:22 AM), https://www.businessinsider.com/amazonopened-22-years-ago-see-the-business-evolve-2017-7 [https://perma.cc/L3WM-Q6L9]. 
share in new book purchases. ${ }^{54}$ Accordingly, the book industry's concern shifted to the effect of the expansion of Amazon on brick-and-mortar bookstores. ${ }^{55}$ Brick-and-mortar video stores, such as Blockbuster, and record stores, such as Tower Records, also faced their demise as videos and music became digitally available to consumers. Today, an overwhelming majority of music and video sales are digitally delivered through services like Amazon or streamed online through streaming services, such as Netflix, Hulu, and Spotify. ${ }^{56}$

As online transactions became more prevalent over the years, states called upon Congress to act and change the law to allow transactions by outof-state sellers to be taxed. ${ }^{57}$ However, Congress did not act, so some jurisdictions attempted to find ways to tax out-of-state sellers for the services they provided to consumers within the jurisdiction. ${ }^{58}$ These jurisdictions curated definitions in order to maximize the services that can be taxed under the amusement and recreation category of services. ${ }^{59}$ For example, some states and localities attempted to circumvent the physical presence requirement by enacting laws that require streaming services to pay a sales tax. ${ }^{60}$ A prime

54. Evangelista, supra note 52; Polly Mosendz, Amazon Has Basically No Competition Among Online Booksellers, THE ATLANTIC (May 30, 2014), https://www.theatlantic.com/business/archive/2014/05/amazon-has-basically-no-competition-among-online-booksellers/371917/ [https://perma.cc/BBX9-XELG].

55. Evangelista, supra note 52; Mosendz, supra note 54.

56. Mike Snider, A 'Netflix tax'? Yes, and It's Already a Thing in Some States, USA TODAY (Aug. 18, 2017, 11:08 AM), https://www.usatoday.com/story/tech/news/2017/08/17/netflix-taxyes-and-its-already-thing-some-states/500416001/ [https://perma.cc/837L-B78M]; Steve Dennis, E-Commerce May Be Only 10\% Of Retail, but That Doesn't Tell the Whole Story, ForBES (Apr. 9, 2018, 1:49 PM), https://www.forbes.com/sites/stevendennis/2018/04/09/e-commerce-fake-newsthe-only-10-fallacy/\#50bdc89639b4 [https://perma.cc/ZA3Z-ZM5X].

57. See Molly Schneider, Quill's Call to Action: Will Congress Update Commerce Clause Nexus Requirements in Light of Cloud Computing?, 40 HASTINGS CONST. L.Q. 903, 917 (2013).

58. William L. Fletcher, Jr., Netflix And Quill: Using Access And Consumption To Create A Plan For Taxing The Cloud, 58 WM. \& MARY L. REV. 1029, 1038 (2017).

59. Id. at 1038-39. Examples of out-of-state providers under the amusement and recreation category include Netflix, Hulu, and Spotify.

60. Id. 
example of this attempt is the amusement tax in Chicago. ${ }^{61}$ Chicago's municipal code imposes an amusement tax which applies to those attending or engaging in entertainment or recreational activities that are offered to the public. ${ }^{62}$ In 2015 , the tax was amended to apply to streaming services, which are considered a form of online amusement. ${ }^{63}$ The burden was placed on the seller to decide whether they need to collect the amusement tax based on where the consumer is located and whether the nexus requirement is met. ${ }^{64}$ If a consumer engaged in or participated in an activity that qualified as amusement under the municipal code and the consumer resided in Chicago, or if the consumer's primary business address was in Chicago, Chicago may require the seller to collect and remit an amusement tax. ${ }^{65}$ Sellers determine where and whether a tax will be collected based on the consumer's billing address on their credit card. ${ }^{66}$

Other states went beyond the amusement category and created definitions that would require providers of online services to pay a state sales tax. For example, Massachusetts proposed a regulation to define physical presence to include downloading an app onto a device or accessing a website that in turn downloads cookies onto a device. ${ }^{67}$ Under this regulation, online services that have no physical presence within a state, as defined by Quill, could still be required to pay a state sales tax. ${ }^{68}$ Some states enacted "click through" nexus statutes. ${ }^{69}$ These statutes "define nexus to include out-ofstate sellers that contract with in-state residents who refer customers for compensation."70

61. Id.

62. Chicago Mun. Code $§ 4-156-020$ (2004).

63. Id.

64. Fletcher, supra note 58, at 1038-39.

65. $§ 4-156-020$.

66. Fletcher, supra note 58, at 1039.

67. 830 MASS CODE REGS. 64H.1.7 (2017).

68. $I d$.

69. South Dakota v. Wayfair, Inc., 138 S. Ct. 2080, 2098 (2018).

70. Id. 


\section{South Dakota v. Wayfair ${ }^{71}$ and the Substantial Nexus Prong Today}

The Wayfair decision redefined the "substantial nexus" requirement in the first prong of the test put forth by Complete Auto. The Court in Wayfair changed "substantial nexus" to mean the amount of business conducted in the state, rather than the seller's physical presence in the state. ${ }^{72}$ At issue in Wayfair was a law enacted by the South Dakota Legislature. ${ }^{73}$ The law required a seller to collect and remit a sales tax to the state if the seller delivers $\$ 100,000$ of goods or services into the state, or if the seller completes 200 or more transactions within the state. ${ }^{74}$ The law did not require sellers to have a physical presence within the state. ${ }^{75}$ The Court decided it is not unconstitutional for South Dakota to impose a sales tax on sellers that do not have a physical presence within the state. ${ }^{76}$ This decision changed the definition of substantial nexus from a physical presence within a state to a substantial amount of business done within the state, as determined by South Dakota law. ${ }^{77}$

The Court's decision was based on multiple factors. One of these factors was the South Dakota law that defined substantial nexus as $\$ 100,000$ in receipts or 200 transactions with consumers within South Dakota. ${ }^{78}$ This law created a safe haven for sellers that conduct limited business within a state. ${ }^{79}$

71. Id. at 2105 .

72. Id.

73. Id. at 2099; Collection of Sales Taxes from Certain Out-of-State Sellers, ch. 70, 2016 S.D. Sess. Laws $§ 1$.

74. Collection of Sales Taxes from Certain Out-of-State Sellers $\S 1$.

75. $I d$.

76. Wayfair, 138 S. Ct. at 2099.

77. Collection of Sales Taxes from Certain Out-of-State Sellers $\S 1$.

78. Wayfair, 138 S. Ct. at 2089; Collection of Sales Taxes from Certain Out-of-State Sellers $\S 1$.

79. Id. 
The Court also considered the fact that South Dakota is a member of the SSUTA. ${ }^{80}$ The SSUTA is an agreement between states that simplifies the collection and remittance of sales and use taxes for states and sellers. ${ }^{81}$ In order to become a member of the SSUTA, a state must comply with the requirements set forth by the SSUTA. ${ }^{82}$ Membership in the SSUTA includes the following requirements to:

adopt uniform definitions for taxable and exempt products and services, simplify tax rates by limiting themselves generally to one sales tax rate for all taxable products and services, administer both state and local sales and use taxes at the state level, and adopt uniform rules for sourcing transactions based on where items or services are delivered or used. It also establishes three types of certified technology systems for sellers to use to collect and remit sales taxes to all jurisdictions. Finally, the agreement establishes a multistate organization and mechanisms to administer the agreement and settle tax disputes. ${ }^{83}$

The SSUTA also makes the tax collection process less expensive, especially for interstate transactions by out-of-state sellers because the SSUTA provides administrative benefits, such as free software for compliance and audit protection and standardized definitions. ${ }^{84}$

Lastly, the Court considered the fact that South Dakota would not apply the decision of the Court retroactively. ${ }^{85}$ Retroactive application means states can collect sales taxes on transactions that occurred before the Court

80. Wayfair, 138 S. Ct. at 2098.

81. Judith Lohman, OfFICE OF Legislative ReSEARCH, 2012-R-0340, UpDATE ON Streamlined SALES AND Use TAX AgREEMENT 1, 1 (2012).

82. Id.; see also Streamlined Sales Use and Tax Agreement, Streamlined Sales Tax Governing Board, Inc. 1, 2 (May 3, 2018), https://www.streamlinedsalestax.org/docs/defaultsource/agreement/ssuta/ssuta-as-amended-2018-05-03.pdf?sfvrsn=c5876d7_13 [https://perma.cc/W743-YFQ7] [hereinafter SSUTA].

83. Lohman, OfFice OF Legislative RESEARCH, 2012-R-0340, at 2; see also SSUTA, supra note 82 , at 11 .

84. Lohman, OfFICE OF Legislative RESEARCH, 2012-R-0340, at 1.

85. Wayfair, 138 S. Ct. at 2098. 
rendered the Wayfair decision. ${ }^{86}$ Such application of the decision would create the risk of double taxation, where a transaction that was already taxed would be taxed again. ${ }^{87}$ Each one of these factors was crucial to the Court's decision, and these factors were the primary reason for the Court's ruling.

\section{E. State Reactions to Wayfair}

Since the ruling in Wayfair, states that comply with the factors set forth in Wayfair have been able to adjust to the new substantial nexus requirement. As of June 2018, about twenty-four states had laws in place similar to the nexus laws in South Dakota. ${ }^{88}$ For example, Wisconsin started collecting sales tax from out-of-state sellers on October 1, 2018, as long as the out-ofstate sellers met the nexus requirement set forth in Wayfair. ${ }^{89}$ Some states made laws contingent upon the decision by the South Dakota Supreme Court on remand. ${ }^{90}$ However, about eighteen states, not including those without a sales tax, do not have a tax system in place for out-of-state sellers, so it is unknown if and when they will act. ${ }^{91}$

Some states have provided guidance and notification to sellers on how to collect and remit state sales tax. ${ }^{92}$ This guidance and notification includes potential steps the state will take in implementing the new substantial nexus

86. Id.

87. Id. at 2099 .

88. Tripp Baltz, State of Wayfair: State Group Tells Congress to Butt Out, BLOOMBERG BNA (Aug. 2, 2018), https://www.bna.com/state-wayfair-state-n73014481372/ [https://perma.cc/7AJR-CBCL].

89. Bob Lang, Legislative Fiscal Bureau, South Dakota V. Wayfair, Inc. - Sales And Use Tax Collections On Remote Sales, Wisconsin Legislature 1, 3 (July 2, 2018), http://docs.legis.wisconsin.gov/misc/lfb/misc/165_south_dakota_v_way-

fair_inc_sales_and_use_tax_collections_on_remote_sales_7_2_18.pdf [https://perma.cc/CH4Y9APD].

90. Baltz, supra note 88 .

91. Id.

92. Id. 
requirement. ${ }^{93}$ However, this is not sufficient for out-of-state sellers. ${ }^{94}$ For example, Maryland issued a "tax alert" with questions and answers for outof-state sellers on how to proceed in terms of collecting and remitting a sales tax. ${ }^{95}$ The alert did not go into depth about when sales tax should be collected and remitted or whether sellers are required to pay the sales tax retroactively. ${ }^{96}$ As a result, the vagueness of the guidance and notifications published by these states left many out-of-state sellers confused as to whether they need to collect a sales tax and how they should remit it to the state.

States that do not impose a sales tax are also affected by the Wayfair decision because sellers within these states can still be responsible for collecting and remitting a sales tax in other states that do require out-of-state sellers to collect a sales tax. ${ }^{97}$ New Hampshire is a prime example of a state attempting to protect its sellers from sales taxes imposed by other states. ${ }^{98}$ In New Hampshire, a draft bill was circulated in the legislature that would require other states to seek the approval of New Hampshire's Department of Justice in order for those states to impose a sales tax on sellers from New Hampshire. ${ }^{99}$ Thus, even states that do not collect a sales tax, such as New Hampshire, are affected by and responding to the Wayfair decision.

A few states with more complex systems of taxation are working to enact legislation as a response to Wayfair. For example, some states have multiple jurisdictions and the sales tax varies based on the jurisdiction within

93. Id.

94. Jeffrey S. Reed, A Range of State Responses After Wayfair, LEXOLOGY (Sept. 27, 2018), https://www.lexology.com/library/detail.aspx?g=4d5d0ac9-e17c-489e-a161-8cfb51e236ea [https://perma.cc/4K97-PBHX].

95. See Tax Alert Regarding The United States Supreme Court Decision South Dakota v. Wayfair, COMPTROLLER OF MARYLAND (2018), https://taxes.marylandtaxes.gov/Resource_Library/Tax_Publications/Tax_Alerts/7.6.18_Sales_Use_Tax_Alert_South_Dakota_v_Wayfair.pdf [https://perma.cc/2FSU-UNJN].

96. See id.

97. Reed, supra note 94.

98. Id.

99. Id. 
the state. ${ }^{100}$ In these states, there is a local sales tax along with a state sales tax, and sellers are liable for the collection of both taxes. ${ }^{101}$ So, the amount of tax a seller collects depends on the locality or jurisdiction to which the item was sold.

The two states that might have the most trouble simplifying their sales tax systems and adapting to the Wayfair decision are Colorado and Louisiana. ${ }^{102}$ Both states have over 300 jurisdictions in which sales taxes are administered, collected, and audited independently from the state sales tax. ${ }^{103}$ In order to take advantage of the Wayfair decision, these states would need to create uniformity amongst the jurisdictions that have various tax rates. ${ }^{104}$ For example, Colorado allows its cities to enforce their own sales tax rate, which can be a different rate from that of the state. ${ }^{105}$ Because Colorado allows cities to create their own taxes, hundreds of jurisdictions in Colorado are able to define and administer sales taxes independently from the state. ${ }^{106}$

Similar to Colorado, Louisiana also has jurisdictions that impose their own sales tax rates. However, Louisiana is attempting to create uniformity amongst its jurisdictions with various tax rates. Louisiana enacted a law that went into effect on January 1, 2019, which adopts the substantial nexus requirement of Wayfair. ${ }^{107}$ The law also creates a single collection entity for sales taxes collected from out-of-state sellers, along with a sales tax board aimed at promoting uniformity and efficiency in administering local sales

100. Joseph Bishop-Henchman, Post-Wayfair Options for States, TAX Foundation (Aug. 29, 2018) https://taxfoundation.org/post-wayfair-options-for-states/ [https://perma.cc/XZN8M4G6].

101. Id.

102. Id.

103. Id.

104. Id.

105. 2018 Colorado Local Government Handbook, LEGISLATIVE COUNCIL STAFF 1, 22 (2018), https://leg.colorado.gov/sites/default/files/2018_local_government_handbook_with_cover_0.pdf [https://perma.cc/G5ZZ-V7C5].

106. Id.

107. La. Rev. Stat. Ann. § 47:301 (2018). 
taxes. ${ }^{108}$ Louisiana officials are also considering enforcing a uniform tax rate for out-of-state sellers. ${ }^{109}$

Another example of a state that simplified their complex tax structure is Alabama. Alabama simplified their sales tax by enforcing a flat tax rate of eight percent. ${ }^{110}$ The flat rate tax holds out-of-state sellers liable for collecting and remitting a flat sales tax, rather than collecting taxes based on jurisdiction. ${ }^{111}$ Though states like Alabama and Louisiana were able to adopt laws to simplify their system of taxation and collect sales taxes from out-ofstate sellers, how Colorado will act remains uncertain.

\section{F. Congress's Constitutional Power to Act}

Though the Wayfair decision was tailored for South Dakota, the Court in Wayfair left room for Congress to step in and set a standard substantial nexus requirement for all the states that intend to collect sales taxes. ${ }^{112} \mathrm{Be}-$ fore Congress can act, however, Congress must have the constitutional authority to act. The Commerce Clause of the Constitution provides Congress with the power to act in order to regulate interstate commerce. ${ }^{113}$ According to the Commerce Clause, " $\mathrm{t}$ ]he Congress shall have power to ... regulate commerce . . among the several states . . .."114 Under this clause, Congress may regulate the channels and instrumentalities of interstate commerce, intrastate economic activities with a substantial effect on interstate commerce, and products that move between states. ${ }^{115}$

The transactions made by out-of-state sellers with in-state consumers are considered interstate commerce. The transactions involve products that

108. Bishop-Henchman, supra note 100.

109. Id.

110. La. Rev. Stat. Ann. § 47:301 (2018).

111. $§ 40-23-193$.

112. Wayfair, 138 S. Ct. at 2098.

113. U.S. CONST. art. I, $\S 8$, cl. 3.

114. $I d$.

115. Commerce Clause, LAw Shelf Educational Media, https://lawshelf.com/courseware/entry/the-commerce-clause [https://perma.cc/SZ8M-J8WG]. 
move between state lines, thus placing these transactions under Congressional authority. So, an act by Congress that regulates the taxation of outof-state sellers would not be an imposition by Congress onto states' powers, but rather regulation by Congress of transactions between out-of-state sellers and in-state consumers. ${ }^{116}$

The purpose of the Commerce Clause is to ensure fairness in the taxation of out-of-state sellers and in-state sellers. For this reason, the Commerce Clause also operates negatively and is known as the dormant Commerce Clause. ${ }^{117}$ Under the dormant Commerce Clause, if Congress does not act with regard to interstate commerce, this inaction does not automatically permit states to act, though states do have the power to tax out-of-state sellers so long as the seller's activities fall within the test set forth by Complete Auto and modified by Wayfair. ${ }^{118}$ The dormant Commerce Clause functions to prevent states from implementing taxes or regulations that would place an "undue burden" on interstate commerce. ${ }^{119}$ The clause also functions to prevent discrimination by states against out-of-state sellers by providing Congress with the authority to regulate commerce amongst the states. ${ }^{120}$ For example, a tax that favors local business or products, such as an exemption that only applies to alcoholic beverages that have been produced within the state, would be a dormant Commerce Clause violation. ${ }^{121}$

116. Id.

117. Craig B. Fields \& Michael W. McLoughlin, An Analysis of the Historical Development of the Dormant Commerce Clause in State Tax Cases, 2007 ST. \& LoC. TAX LAw. 39, 42 (2007).

118. Id. at 48 .

119. Joel Michael, Constitutional Restrictions on State Taxation: The Prohibition on Discriminating Against Interstate Commerce, MINNESOTA HousE OF REPRESENTATIVES RESEARCH DEPARTMENT (Sept. 2018), https://www.house.leg.state.mn.us/hrd/pubs/ss/clssintc.pdf [https://perma.cc/U3YV-A3BT].

120. Robert Verbruggen, The Supreme Court Just Gave States Power to Tax Online Sales, NATIONAL REVIEW (June 22, 2018, 2:13 PM), https://www.nationalreview.com/2018/06/onlinesales-tax-supreme-court-ruling-make-congress-act/ [https://perma.cc/4FJH-Z7QH].

121. Michael, supra note 119. 


\section{The OPTIONS OF CONGRESS}

\section{A. Congress Should Not Remain Silent}

By not taking action, Congress can allow the states to decide how to proceed after Wayfair. This seems to be a favorable option amongst states. After the Wayfair decision, at a summit hosted by the National Conference of State Legislatures, a directive was passed calling congressional action "unnecessary." 122 Some states do not believe Congress needs to take action on this matter unless states "act foolish[ly]," which has not been the case so far. $^{123}$

There are some advantages if Congress does not act. For instance, each state will have the freedom to adopt legislation that is convenient for the tax structure of that state. States would continue to adopt tax policies that are tailored to the issues they would face in adopting Wayfair's requirements. For example, as previously discussed, Colorado's main concern is reconciling its 300 jurisdictions that have additional local taxes. ${ }^{124}$ If Congress does not act, Colorado would have the freedom to come up with a solution to reconcile the collection of state and local sales taxes from out-of-state sellers.

Congressional inaction has disadvantages as well. Most states have passed their own tax laws that go into effect at different times with different requirements. ${ }^{125}$ Out-of-state sellers are burdened because of the need to stay updated with each state's tax laws, when these laws go into effect, and what their requirements are. ${ }^{126}$ While some sellers with more resources are able to stay updated on the developments within each state, other sellers that lack these resources are unduly burdened. The burden of conducting business

122. Tripp Baltz, State of Wayfair: State Group Tells Congress to Butt Out, BLOOMBERG BNA (Aug. 2, 2018), https://www.bna.com/state-wayfair-state-n73014481372/ [https://perma.cc/7AJR-CBCL].

123. Id.

124. Joseph Bishop-Henchman, Post-Wayfair Options for States, TAX Foundation (Aug. 29, 2018), https://taxfoundation.org/post-wayfair-options-for-states/ [https://perma.cc/XZN8M4G6].

125. Howard Gleckman, Congress Has Had 26 Years to Address Online Sales Taxes; It Just Failed One More Time, FORBES (March 21, 2018), https://www.forbes.com/sites/beltway/2018/03/21/congress-has-had-26-years-to-address-online-sales-taxes-it-is-about-to-fail-onemore-time/\#3835049f139d [https://perma.cc/7NCZ-RBYP].

126. $I d$. 
nationwide discourages smaller-scale businesses from operating on a national level, which negatively impacts small businesses by decreasing their amount of sales.

Many smaller businesses are further burdened by compliance costs that arise from having a nexus within a state. For example, Laurence Kotlikoff runs a small online business. ${ }^{127}$ Prior to the Wayfair decision, Kotlikoff had nexus in six states because he had employees in those states. ${ }^{128}$ When he hired someone in a state, Kotlikoff's business would register to pay sales tax in that state. ${ }^{129}$ Not only did Kotlikoff's business pay a sales tax in the states where the business had a nexus, but the business also needed to file tax returns and reports in each state where there was a nexus. ${ }^{130}$ Thus, compliance costs were about $\$ 50,000$ a year for Kotlikoff's business. ${ }^{131}$ However, with the Wayfair decision, such costs are estimated to be $\$ 150,000$ since Kotlikoff's business will have a nexus in more states. ${ }^{132}$ Thus, higher costs that arise from complying with each state's nexus requirements might discourage Kotlikoff's business from selling its products into different states. ${ }^{133}$

\section{B. Congress Should Enact a Uniform Definitions for Terms}

If Congress is to act, Congress should establish a universal definition for what qualifies as goods and what qualifies as services. Currently, not all states charge a sales tax on services, so a definition delineating goods and

127. Laurence Kotlikoff, Did The Supreme Court Potentially Bankrupt Tens of Thousands of Small Online Businesses?, FORBES (June 21, 2018, 3:14 PM), https://www.forbes.com/sites/kotlikoff/2018/06/21/did-the-supreme-court-just-bankrupt-tens-of-thousands-of-small-online-businesses/\#4ef1da9427aa [https://perma.cc/H2AG-T8KF].

128. Id.

129. $I d$.

130. Id.

131. $I d$.

132. Id.

133. Id. 
services can provide out-of-state sellers with guidance as to when they are expected to collect a sales tax. ${ }^{134}$

Congress should adopt definitions that comply with the definitions set forth in the SSUTA. ${ }^{135}$ The SSUTA includes definitions that member states are required to follow. ${ }^{136}$ If Congress codifies a different definition for a word that is already defined in the SSUTA, states that are already members of the SSUTA would be split between being required to follow two distinct definitions. In order to avoid confusion, if a word is already defined in the SSUTA, Congress should adopt the same, or broader, definition.

As this article will discuss, Congress should require states to join the SSUTA if these states intend to collect a sales tax from out-of-state sellers. ${ }^{137}$ If membership in the SSUTA is a prerequisite for states to collect a sales tax, states will automatically be required to follow the definitions set forth in it, which include the definitions for "goods" and "services." 138 Doing so will eliminate the need for Congress to define these terms.

On the other hand, if Congress does not make membership in the SSUTA a prerequisite for states to collect a sales tax, Congress should adopt uniform definitions for certain words. An example of one of these words is the term "goods." In order to avoid confusion, and in the interest of maintaining consistency over time, Congress should codify the definition of tangible personal property (TPP) set forth in the SSUTA to define goods. The SSUTA defines TPP as "personal property that can be seen, weighed, measured, felt, or touched, or that is in any other manner perceptible to the senses.

134. Sales Tax on Services by State, AVALARA, https://www.avalara.com/us/en/learn/whitepapers/service-taxability-by-state.html [https://perma.cc/Y3WYQAAE].

135. The SSUTA is an agreement between states that simplifies the collection and remittance of state and local sales and use taxes. Over twenty states are currently full members of the SSUTA. Member states are bound by the definitions in the SSUTA. Judith Lohman, OFFICE OF Legislative ReSEARCH, 2012-R-0340, Update on StREAmlined SALES AND UsE TAX AGREEMENT 1, 1 (2012).

136. See Streamlined Sales Use and Tax Agreement, Streamlined SAlES TAX GOVERNING BOARD, INC. 1, 8 (May 3, 2018), https://www.streamlinedsalestax.org/docs/defaultsource/agreement/ssuta/ssuta-as-amended-2018-05-03.pdf?sfvrsn=c5876d7_13

[https://perma.cc/W743-YFQ7].

137. See infra Part II.C.

138. SSUTA, supra note 136 , at 52. 
[This] includes electricity, water, gas, steam, and prewritten computer software."139

Another example of a word that should have a universal definition is the term "services." The new substantial nexus requirement under Wayfair allows states to tax online and streaming services since a physical presence is no longer necessary for a state to tax an out-of-state seller. Congress should adopt a broad definition of services in response to Wayfair, thus allowing the states to define and tax each category as they see fit.

If Congress adopts a broad definition, the states with pre-existing definitions of services will not need to take additional action to update their laws. States will also have more autonomy in choosing which services to tax. Additionally, states that are members of the SSUTA already have definitions for digital products, which fall under services, so these states would not need to be concerned with conforming to a definition set forth by Congress if Congress adopts a broad definition of services. ${ }^{140}$ For these reasons, Congress should adopt a broad definition of services in response to Wayfair in order to allow the states to define and tax each category as they see fit.

\section{Congress Should Codify Wayfair's "Substantial Nexus" Requirement}

In order to ensure states are reacting to Wayfair in a constitutional and foreseeable manner, Congress can require states to adopt the factors the Court considered in Wayfair. So far, about eleven states have already adopted the provisions set forth in Wayfair, which includes the minimum substantial nexus requirement, membership in the Streamlined Sales and Use Tax Agreement (SSUTA), and a ban on retroactive application of the new substantial nexus requirement. ${ }^{141}$ Since Congress has the constitutional

139. Id. at 100 .

140. Id. The SSUTA defines the following digital products: "Specified digital products" means electronically transferred; "Digital Audio-Visual Works" which means a series of related images which, when shown in succession, impart an impression of motion, together with accompanying sounds, if any, "Digital Audio Works" which means works that result from the fixation of a series of musical, spoken, or other sounds, including ringtones, and "Digital Books" which means works that are generally recognized in the ordinary and usual sense as "books." For purposes of the definition of "digital audio works," "ringtones" means digitized sound files that are downloaded onto a device and that may be used to alert the customer with respect to a communication. For purposes of the definitions of "specified digital products," "transferred electronically" means obtained by the purchaser by means other than tangible storage media.

141. South Dakota v. Wayfair, Inc., 138 S. Ct. 2080, 2099 (2018). 
power under the Commerce Clause to regulate commerce between states, Congress can also enact a law different from the provisions set forth in Wayfair. $^{142}$

\section{Online Marketplaces}

According to the U.S. Government Accountability Office, an organization that provides factual information to Congress, "[t]he rise of e-marketplaces, such as eBay, Etsy, and Amazon Marketplace, has complicated nexus determinations." "143 Amazon defines an e-marketplace, or a marketplace facilitator, as "a marketplace that contracts with third party sellers to promote their sale of physical property, digital goods, and services through the marketplace." "144 The marketplace facilitator then advertises the products, takes orders from customers, and collects the payments for third-party sellers. ${ }^{145}$ So, a seller that sells books on Amazon would be a third-party seller and Amazon would be the facilitator.

A facilitator has multiple sellers, so Congress needs to address whether the third-party seller or the marketplace facilitator should collect and remit the sales tax to the state. If the burden is placed on third-party sellers to collect and remit the sales tax, then each seller would collect and remit the sales tax individually after the seller meets the nexus requirement. If the burden is placed on the facilitator to collect and remit the sales tax, then the facilitator would collect and remit the sales tax on behalf of its sellers once the facilitator, as a whole, meets the nexus requirement.

States prefer to collect sales tax from facilitators rather than from thirdparty sellers. For example, the Department of Revenue of South Carolina is in litigation with Amazon Services, LLC for \$1.9 billion in sales taxes that

142. U.S. CONST. art. I, $\S 8, \mathrm{cl} .3$.

143. U.S. Gov'T ACCOUNTABILITY OFF., GAO-18-114, REPORT TO CONGRESSIONAL REQUESTERS: SALES TAXES, STATES COULD GAIN REVENUE FROM EXPANDED AUTHORITY, BUT BuSINESSES ARE LIKELY TO EXPERIENCE COMPLIANCE COSTS 10 (2017).

144. Marketplace Tax Collection, AMAZON, https://www.amazon.com/gp/help/customer/display.html?nodeId=202211260 [https://perma.cc/4SLJ-XSTS].

145. Baltz, supra note 122 . 
Amazon should pay on products sold by third-party sellers through Amazon's marketplace. ${ }^{146}$ The Department argues that Amazon itself is responsible for the collection and remittance of the sales tax on taxable goods sold through Amazon, even if the product sold is owned and sold by a third-party seller. ${ }^{147}$ The Department also released a draft revenue ruling explaining that a facilitator is liable for the collection and remittance of a sales tax, even if a third party contributes the goods to the facilitator, such as in a consignment sale or auction. ${ }^{148}$

Other states, such as Alabama, Oklahoma, and Pennsylvania, have already enacted laws that provide facilitators with the option to either collect and remit a sales tax or to follow the reporting and consumer notification rules so that the consumer has the knowledge that they need to pay a use tax on the items purchased. ${ }^{149}$ However, in the past, consumers did not pay the use tax they were required to pay and states did not enforce the collection of the use tax. ${ }^{150}$

Congress should adopt a law that would require facilitators to collect and remit a sales tax once the facilitator and its third-party sellers, as a whole, have made enough sales to meet the substantial nexus requirement. Under this scenario, if Amazon makes enough sales to meet the nexus requirement through products sold directly by Amazon, all sales made by third-party sellers through Amazon would be subject to a sales tax as well, and vice versa. The burden would be placed on Amazon to collect and remit the sales tax.

146. Ken Elkins, SC vs. Amazon Sales Tax Case Inching Through Court, CHARLotTE BUSINESS JOURNAL (Jun. 22, 2018, 11:59 AM), https://www.bizjournals.com/charlotte/news/2018/06/22/sc-v-amazonsales-tax-case-inching-through-court.html [https://perma.cc/U442-C23R].

147. S.C. Revenue Ruling \#18-X Draft, CirCulated FOR Public Comment (Aug. 10, 2018).

148. SC REVENUE RULING \#18-X DRAFT.

149. Announces Sales and Use Tax Guidance for Online Sellers, ALABAMA DEPARTMENT OF REVENUE, 1 (July 3, 2018), https://revenue.alabama.gov/2018/07/03/ador-announces-sales-anduse-tax-guidance-for-online-sellers/ [https://perma.cc/S29L-JVGC]. Joseph Bishop-Henchman, Testimony: Post-Wayfair Options for Congress, 1 at 2, TAX Foundation (July 24, 2018), https://taxfoundation.org/post-wayfair-options-congress/ [https://perma.cc/7ELX-DNDJ].

150. Marc Lifsher et al., State to Target Web Retailers for Sales Taxes, Los ANGELES TIMES (Aug. 31, 2012), http://articles.latimes.com/2012/aug/31/business/la-fi-0831-internet-taxescrackdown-20120831 [https://perma.cc/ZY8E-ZXBT]. 
Placing the burden on the facilitator to collect and remit sales taxes alleviates third-party sellers from the need to track all their sales within each state and through different facilitators. For example, if a seller uses both eBay and Amazon to sell items throughout the nation, the seller would need to track the amount of sales the seller made into each state through both facilitators. However, if the facilitator is responsible for the collection of a sales tax, the seller would not need to worry about how many sales were made through Amazon or eBay or to which state. The burden would be on Amazon and eBay to track the amount of sales made into each state and calculate where and whether the nexus requirement was met.

Further, the facilitator is better equipped to collect a sales tax on all sales made by third-party sellers through the facilitator. Since the facilitator is a larger organization, the facilitator likely has the resources necessary to keep track of sales into other states. Placing the burden on the facilitator also streamlines the remittance process because only the facilitator would need to register for a sales tax license with the states where sales taxes will be remitted. Lastly, placing the burden on the facilitator encourages third-party sellers and smaller businesses to sell their products to other states. These sellers would be more likely to sell their products to other states because they would not need to worry about the need to keep track of sales in order to collect taxes or the need to register with states in order to remit taxes.

Even if Congress requires facilitators to collect and remit a sales tax on behalf of their sellers, such an act would leave many questions unanswered. There are still many online sellers who do not conduct business through facilitators and prefer to sell their product through their own website, which has its own benefits for sellers. ${ }^{151}$ An act by Congress that requires facilitators to collect and remit a sales tax would shift the burden from the sellers to

151. Kristina Lopienski, Website vs. Marketplace: Where Should Your Ecommerce Company Sell Online?, 1 at 4-5, SHIPBOB: THE SHIPBOB BLOG (Dec. 1, 2017), https://www.shipbob.com/blog/online-store-vs-marketplace-ecommerce-website-sell/ [https://perma.cc/5AHF$H 3 U F]$. The benefits of selling through the seller's own website include: "[e]stablish and maintain full control over your brand. When you run your own ecommerce website, you have total control over what it looks like, what it says, and how it works. It doesn't have to be generic or boring. This is your chance to show the world your brand's personality. There are very few restrictions, cookiecutter guidelines, and character limits. You get to create the shopping experience that you want for your customers. Many ecommerce platforms offer flexibility over design, pre-built templates to choose from, and integrations with other systems. You can retarget shoppers to become repeat buyers. One of the greatest advantages of managing your own website is that you get direct access to your customers. This enables better customer service and ultimately more upsell possibilities. You can target people who visit your site with ads, market to those who have already purchased from you, and stay connected in the future. Email list building helps you build awareness, bring in steady revenue, and run promotions to get rid of inventory." 
the facilitators, but such an act would still leave open the question of how sellers who prefer to sell their products independently should proceed in light of Wayfair.

\section{Setting a Uniform Minimum Nexus Requirement}

A major issue that Congress will face is setting a minimum nexus requirement. The minimum nexus requirement would set a threshold for when a state can collect sales taxes from an out-of-state seller for transactions made to consumers in the state. If an out-of-state seller meets a state's nexus requirement, the seller would be required to collect and remit a state sales tax to the state where the requirement is met. A nexus requirement creates a safe haven for small-scale out-of-state sellers and protects them from collecting and remitting a state sales tax. ${ }^{152}$ For example, in South Dakota, the nexus requirement is $\$ 100,000$ in receipts or 200 transactions with in-state consumers. ${ }^{153}$ Thus, out-of-state sellers that have not met the South Dakota requirement will not be required to collect or remit a sales tax to South Dakota.

In the interest of fairness and consistency, Congress could forgo setting a minimum nexus requirement, which would allow states to tax all out-ofstate sellers for every transaction made within the state. Without a nexus requirement, all sellers, whether out-of-state or in-state, would collect and remit a sales tax on every transaction. With a nexus requirement, out-ofstate sellers that do not meet the requirement would be exempt from collecting and remitting a sales tax. Thus, if Congress forgoes setting a nexus requirement, Congress would level the playing field between out-of-state sellers and in-state sellers because all sellers would collect and remit sales taxes.

However, without a nexus requirement, sellers would be discouraged from selling their products to other states because a requirement for all sellers to collect and remit a sales tax would be unduly burdensome. The compliance costs would outweigh the benefits of selling to a foreign state. ${ }^{154}$ For example, a seller who only makes a few small sales within another state would be required to register with the state's tax department and remit a sales tax to the state. In addition to burdening out-of-state sellers, the lack of a

152. Bishop-Henchman, supra note 149 , at 3.

153. Collection of Sales Taxes from Certain Out-of-State Sellers, ch. 70, 2016 S.D. Sess. Laws $§ 1$.

154. See Wayfair, 138 S. Ct. at 2104. 
nexus requirement would burden state tax departments as well. Since more sellers will be required to remit a sales tax, the tax department of each state would need to register more sellers in order to collect sales taxes from them.

Alternatively, Congress could adopt a low nexus requirement. This would exclude minor transactions that an out-of-state seller had with a taxing state, but would require sellers who conduct sufficient business within a state to collect and remit their fair share of sales taxes to that state. A low nexus requirement will have issues similar to those associated with the lack of a nexus requirement. For example, a low nexus requirement will be unduly burdensome for small-scale sellers since they will likely meet the requirement in a few states. ${ }^{155}$ As Chief Justice Roberts stated in his dissent, "[p]eople starting a business selling their embroidered pillowcases or carved decoys can offer their wares throughout the country - but probably not if they have to figure out the tax due on every sale."156 Thus, a low nexus requirement, similar to no nexus requirement, would discourage sellers from expanding their business due to the high compliance costs associated with the sale of items into foreign states. ${ }^{157}$

On the other hand, a nexus requirement that is too high will also have negative consequences. Such a requirement would exclude more sellers from being required to collect and remit a state sales tax, and thus, deprive many states from the ability to collect sales taxes. States have already suffered losses in tax revenue for years due to the physical presence requirement set by Quill and Congress's inaction to close such a loophole. ${ }^{158}$ Additionally, "[a]ccording to a report issued by the U.S. Government Accountability Office (GAO) in December 2017 ... only 14 to 33 percent of marketplace sales were taxed in 2017; the rest went untaxed because they fell outside state laws." 159

155. Jeffrey S. Reed, A Range of State Responses After Wayfair, LEXOLOGY (Sept. 27, 2018), https://www.lexology.com/library/detail.aspx?g=4d5d0ac9-e17c-489e-a161-8cfb51e236ea [https://perma.cc/4K97-PBHX].

156. Wayfair, 138 S. Ct. at 2104.

157. Kotlikoff, supra note 127 , at 2.

158. Donald Bruce \& William F. Fox, E-Commerce in the Context of Declining States Sales Tax Bases, 53 NAT'L TAX J. 1373, 1374-76 (2000).

159. Gail Cole, Marketplace Sales Tax Laws Explained, Avalara (Apr. 16, 2018), https://www.avalara.com/us/en/blog/2018/04/Marketplace_sales_tax_laws_explained.html [https://perma.cc/8GPQ-2D5E]. See also U.S. GoV'T ACCOUNTABILITY OFF., supra note 143, at 10 . 
South Dakota's nexus requirement is the best threshold Congress could set. If the requirement is nonexistent or set too low, more sellers would be required to collect and remit a state sales tax, making it burdensome for small-scale sellers. However, states will have the opportunity to collect their fair share of sales taxes. On the other hand, if the nexus requirement is set too high, less sellers would be required to collect and remit a state sales tax, leaving states with less tax revenue. An ideal nexus requirement would parallel South Dakota's. South Dakota's requirement is low enough to include sellers who conduct a sufficient amount of business within a state, but not so high as to exclude most sellers from the requirement to collect and remit a state sales tax. Thus, Congress should enact South Dakota's $\$ 100,000$ receipts or 200 transactions minimum substantial nexus requirement.

\section{Determining When There Is a Nexus}

Another issue that Congress should address is when a seller should collect sales taxes. For example, if a seller does not anticipate that they would meet the nexus requirement in a state, the seller might not charge sales tax on the first 200 transactions or $\$ 100,000$ in sales. If the seller later makes enough sales to meet the nexus requirement, will the seller be liable for remittance of the sales tax on the first 200 transactions or $\$ 100,000$ in sales, or will the seller be liable only for sales made after the minimum requirement is met? ${ }^{160}$

Some states have enacted legislation to address this issue. For example, in Colorado, if an out-of-state seller's business grows significantly within the state after the deadline to register for a sales tax license, the seller is required to register for the license once the minimum requirements are met. ${ }^{161}$ In Michigan, if the requirements are met in one calendar year, but sales decrease the next calendar year, the seller is not required to collect and remit a sales tax in the year in which the requirement is not met. ${ }^{162}$ The Department of Revenue of Michigan provided the following examples to clarify the concept of when a seller would owe a sales tax:

160. Information for Out-of-State Retailers, COLORADO DEP'T OF REVENUE: TAXATION DIVISION, $1, \quad$ at $5 \mathrm{https} / / / \mathrm{www}$. colorado.gov/pacific/tax/information-out-state-retailers [https://perma.cc/3BCF-UPTE].

161. Id.

162. Michigan DeP'T of Treasury, Sales and Use Tax NeXus Standards for REMOTE SELLERS, REVENUE AdMinistrative BulLETIN 2018-16, 1 at 3 (2018). 
Example 1: Seller has no physical presence, representational, attributional, or click-through nexus in Michigan. Seller had $\$ 100,001$ of sales into Michigan between January 1, 2017, and December 31, 2017. Seller has nexus in Michigan effective after September 30, 2018 and must begin reporting and remitting tax on all taxable sales from October 1, 2018 forward. Once a seller has nexus due to its economic presence it must remit tax until a calendar year passes in which it does not meet either of the economic nexus thresholds ...

Example 2: Assume the same facts as Example 1; however, Seller has only $\$ 10,000$ of sales and fewer than 200 transactions into Michigan from January 1, 2018 through December 31, 2018. Seller must report and remit tax for all taxable sales made after September 30, 2018, through December 31, 2018. Seller no longer has nexus due to its economic presence beginning on January 1,2019 , and may therefore cease remitting and reporting tax after that date. ${ }^{163}$

Another example is Washington. There, an out-of-state seller has two options prior to meeting the substantial nexus requirement. The seller can either (1) register the business and collect and remit a sales tax, or (2) comply with the use tax notice and reporting requirements. ${ }^{164}$ Under the use tax notice and reporting system, the seller would post a notice on a platform to inform consumers in Washington about the use tax that is due on certain purchases. ${ }^{165}$ The consumer would then file a use tax return with a payment that would otherwise be a sales tax collected by the seller. ${ }^{166}$ However, Washington's approach is not feasible. Prior to Wayfair, consumers were responsible for the remittance of a use tax on items purchased from out-of-

163. Id. at $2-3$.

164. Marketplace Fairness - Leveling the Playing Field, DEP'T OF REVENUE WASH. ST., https://dor.wa.gov/find-taxes-rates/retail-sales-tax/marketplace-fairness-leveling-playing-field [https://perma.cc/85QT-P279] [hereinafter Marketplace Fairness].

165. Use Tax Notice and Reporting Requirements, DeP'T OF ReVEnUE Wash. ST., https://dor.wa.gov/find-taxes-rates/retail-sales-tax/marketplace-fairness-leveling-playing-

field/use-tax-notice-and-reporting-requirements-referrers [https://perma.cc/9SXW-F34C] [hereinafter Use Tax Notice and Reporting Requirements].

166. $I d$. 
state sellers, but states did not go after consumers for the use tax that they owed the state, so consumers did not pay the use tax. ${ }^{167}$

Instead of an approach like Washington's, Congress should adopt a combination of the approaches of Colorado and Michigan. Under this approach, a seller will collect and remit sales taxes on transactions that exceed the nexus requirement each year. Once a seller meets the nexus requirement, the seller will register for a sales tax license. The seller will also collect and remit the sales tax on transactions after the nexus requirement was met. Similarly, the seller will not be required to collect a sales tax on transactions made in a year in which the seller did not meet the nexus requirement.

Congress should also act to prevent sellers from using the nexus requirement to avoid the collection and remittance of sales taxes on transactions made before the nexus requirement is met. If an out-of-state seller is highly likely to meet the nexus requirement, the seller should collect a sales tax on transactions made before the nexus requirement is met because the nexus requirement functions primarily as a safe haven for small-scale sellers as opposed to an exemption for transactions made before the nexus requirement is met. ${ }^{168}$ In order to ensure sellers do not use the nexus requirement as an exemption, Congress should enact a law that requires sellers who met the nexus requirement for three or more consecutive years to collect and remit a sales tax on all transactions made within the year, including transactions made before the nexus requirement was met.

\section{Membership in the Streamlined Sales and Use Tax Agreement (SSUTA)}

Another factor the Court in Wayfair considered when rendering a decision was the fact that South Dakota was a member of the SSUTA. Of the twenty-plus states that have laws in place similar to the nexus laws in South Dakota, nine states are not members of the SSUTA. ${ }^{169}$ Other states do not have nexus laws similar to South Dakota, nor are they members of the SSUTA.

There are many benefits associated with membership in the SSUTA. Participation in the SSUTA takes the burden off sellers. A seller registers to

167. Lifsher et al., supra note 150.

168. Wayfair, 138 S. Ct. at 2089.

169. Ryan Prete, After 'Wayfair', Which States Are Ready to Tax Online Purchases? (1), BLOOMBERG BNA (June 27, 2018), https://www.bna.com/wayfair-states-ready-n73014476940/ [https://perma.cc/7RY3-G3E5]. 
remit a sales tax with the SSUTA rather than with each state, and the SSUTA automatically registers the seller with all member states. ${ }^{170}$ This streamlined registration process especially benefits sellers that do not have the resources to register with every state. The SSUTA also provides free software to sellers through which the sellers can remit their sales taxes to states. ${ }^{171}$ This software releases sellers from liability for errors that occur from relying on the software, which in turn protects sellers from being subject to multistate audits. ${ }^{172}$

Since the SSUTA will automatically register the seller with all member states, membership in the SSUTA benefits states because the burden is taken off state tax organizations that would otherwise be responsible for registering out-of-state sellers. ${ }^{173}$ For example, in California, the California Department of Tax and Fee Administration (CDTFA) registers sellers and collects sales taxes. ${ }^{174}$ If California does not participate in the SSUTA, the CDTFA will be burdened with registering each seller who meets the state's nexus requirement. ${ }^{175}$

In order to be a member of the SSUTA, one of the requirements is a simplified tax rate. ${ }^{176}$ However, some states do not qualify for membership in the SSUTA because of the complicated tax systems they have in place, which leads to non-uniformity within the state. ${ }^{177}$ For example, Colorado has over 300 jurisdictions that impose their own sales and use tax, which has led to different sales taxes being imposed in different jurisdictions within

170. Bishop-Henchman, supra note 152 at 12.

171. Id. at 5 .

172. $I d$.

173. Id.

174. State and Local Tax Partner Comments on Wayfair Decision, PILLSBURY LAW (July 18, 2018), https://www.pillsburylaw.com/en/news-and-insights/state-and-local-tax-partner-comments-on-wayfair-decision.html [https://perma.cc/9HJK-GMMW].

175. Id.

176. Lohman, OFFICE OF LEGISLATIVE RESEARCH, 2012-R-0340, at 2.

177. Fredrick J. Nicely \& Nikki E. Dobay, To Be or Not to Be: Will Colorado and Other Non-SSUTA States Join the SSUTA?, BLOOMBERG BNA (Aug. 4, 2017), https://www.bna.com/notcolorado-nonssuta-n73014462714/ [https://perma.cc/BG6N-CCH8]. 
Colorado. ${ }^{178}$ Another example of a state with a complicated tax system is Arizona. Arizona has a sales tax known as the Transaction Privilege Tax (TPT), which allows each city within Arizona to impose their own sales tax. ${ }^{179}$ Under the TPT, a seller is required to obtain a license for each city in which a seller does business. ${ }^{180}$

If states such as Colorado or Arizona with multiple taxing jurisdictions want to tax out-of-state sellers for transactions made within the state, these states should either simplify their system of taxation or establish a flat rate tax on out-of-state sellers in order to conform with SSUTA standards. ${ }^{181}$ Though the purpose of multiple taxing jurisdictions is to provide those jurisdictions with the autonomy to govern themselves, this system of taxation is burdensome for out-of-state sellers. ${ }^{182}$ It is already burdensome for an outof-state seller to keep track of transactions made with each state, and it would be even more burdensome to require the seller to keep track of transactions made within each jurisdiction of the state.

Due to the many benefits associated with membership in the SSUTA, Congress should require a state to be a member of the SSUTA if the state intends to collect a sales tax from out-of-state sellers. ${ }^{183}$ While some states, like Colorado and Arizona, would need to create sales tax laws for out-of-

178. $I d$.

179. Id.

180. Transaction Privilege Tax, AZ. DEP'T OF REVENUE, https://azdor.gov/transactionprivilege-tax-tpt [https://perma.cc/ESB9-M38R].

181. In order to avoid constitutionality issues regarding discrimination amongst states (one state establishing policies that favor its own state over another), the flat rate tax Colorado and similarly situated states establish should be equal to or lower than the lowest sales tax rate within the state. If the tax out-of-state sellers are required to collect is higher than the lowest tax rate within the state, in-state sellers would collect a lower tax rate than out-of-state sellers in some of the jurisdictions within the state. This could be seen as the state favoring sellers within its own state over sellers outside of the state, which would create discrimination issues between the in-state and outof-state sellers. See Craig B. Fields \& Michael W. McLoughlin, An Analysis of the Historical Development of the Dormant Commerce Clause in State Tax Cases, 2007 ST. \& LOC. TAX LAW. 39,42 (2007).

182. Howard C. Klemme, The Powers of Home Rule Cities in Colorado, 36 U. ColO. L. REV. 321, 322 (1964).

183. The SSUTA itself has requirements for states to follow if they want to be members of the agreement. However, the SSUTA does not establish a nexus requirement, nor does it address whether a new nexus requirement should be applied retroactively. Thus, Congress would still need to address the issues of a nexus requirement and retroactivity separately. 
state sellers in order to conform with SSUTA requirements, the benefits of the streamlined registration process of the SSUTA outweigh the burden of such changes. ${ }^{184}$

\section{The Doctrine of Retroactivity}

In Wayfair, one of the major factors that led to the decision was that the substantial nexus requirement would not apply retroactively, which means South Dakota would not require out-of-state sellers to remit sales taxes on transactions prior to the Wayfair decision. ${ }^{185}$ So far, most states apply the decision prospectively. ${ }^{186}$ In order to codify Wayfair, Congress should enact a law that prohibits states from requiring out-of-state sellers to remit a sales tax for transactions that occurred before the Wayfair decision, even if the case is pending.

Generally, the question of whether a court decision should apply retroactively or prospectively is under judicial discretion. ${ }^{187}$ However, in Harper v. Virginia Dept. of Taxation, ${ }^{188}$ the Supreme Court held:

When this Court applies a rule of federal law to the parties before it, that rule is the controlling interpretation of federal law and must be given full retroactive effect in all cases still open on direct review and as to all events, regardless of whether such events predate or postdate our announcement of the rule. ${ }^{189}$

184. Nicely \& Dobay, supra note 177 .

185. Wayfair, 138 S. Ct. at 2098.

186. Annette Nellen, State Reactions to Wayfair Decision, BlogSPOT (June 25, 2018), http://21stcenturytaxation.blogspot.com/2018/06/state-reactions-to-wayfair-decision.html [https://perma.cc/W6RV-CCE].

187. Supreme Court rulings regarding retroactive application have fluctuated in recent years, so it is difficult to determine where the Court stands on this issue today. See e.g. Metcalf v. Felec Services, 784 P.2d 1386 (Alaska 1990); Blackwell v. Com., State Ethics Com'n, 527 Pa. 172 (1991); Huston v. F.D.I.C., 800 S.W.2d 845 (Tex. 1990).

188. Harper v. Va. Dep't of Taxation, 509 U.S. 86, 97 (1993).

189. Id. 
Harper created a general presumption that Supreme Court decisions of federal law apply to pending cases and prior events. ${ }^{190}$ Although the general presumption is for courts to apply the Wayfair decision to pending cases, the outcome in Wayfair was heavily based on the fact that South Dakota would not apply the Court's decision on past transactions. ${ }^{191}$ For this reason and the reasons listed below, the Wayfair decision should not apply to pending cases filed prior to the Court's decision. Instead, courts should use the physical presence standard under Quill to determine whether a nexus exists for a seller in cases that predate the Wayfair decision.

There are some benefits associated with retroactively applying Wayfair. Retroactive application would further the decision's operation by correcting past errors and remedying the states' failure to collect use tax from consumers. States can recover taxes that were supposed to be paid to the state but were not because of the physical presence requirement under Quill that excused online retailers from the collection and remittance of a sales tax.

However, the issues associated with retroactivity are far greater than any benefit a state would receive from retroactivity. First, a retroactive application will lead to double taxation of the same transaction. ${ }^{192}$ Since a use tax was already imposed upon the consumer for the purchase of the good or service, a requirement for the seller to also pay a sales tax on the transaction would mean the sale is taxed twice. ${ }^{193}$ Second, requiring sellers to pay state sales taxes for past periods would be impractical for sellers and state tax organizations. ${ }^{194}$ Since the sellers did not charge a sales tax for prior transactions, sellers will need to figure out a way to pay the sales tax on transactions for which they did not collect a sales tax. Third, retroactive application of the decision will also lead to major administrative issues because state tax organizations would need to track all sellers that met the nexus requirement and require those sellers to pay a sales tax on their transactions. Since this would place an undue burden on state tax organizations and out-of-state sellers, Congress should ban the application of the Wayfair decision for

190. Id.

191. Wayfair, 138 S. Ct. at 298.

192. Zach Gladney, Charles Wakefield, INSIGHT: 'Wayfair': What Are the Practical Retroactivity Concerns?, BLOOMBERG BNA (July 19, 2018), https://www.bna.com/insight-wayfairpractical-n73014477734/. [https://perma.cc/8ZYJ-W24U].

193. Id.

194. Id. 
transactions that occurred on previous transaction, even if the case was already pending.

\section{Overall Advantages and Disadvantages of Congressional Action}

There are many advantages if Congress acts. If Congress enacts the above requirements, such action would simplify the collection and remittance of sales taxes for both states and sellers. Under a uniform system, sellers will not need to remain updated on each state's sales tax laws, when the laws go into effect, and how to comply with these laws. Instead, sellers will have a uniform guideline that would apply to all states. Uniformity would especially benefit sellers who conduct business on a smaller scale in other states because these sellers are unlikely to have the resources to stay updated on the tax laws of each state.

There are some disadvantages associated with Congressional action as well. If Congress acts, some states may have difficulty implementing the requirements. ${ }^{195}$ However, only a few states will find it difficult to conform with the Wayfair requirements and the benefits of a uniform system outweigh the burden such a system would impose on a few states. Additionally, a uniform requirement might even pressure some of these states to update and simplify their tax laws so that they are better able to implement the Wayfair requirements.

\section{CONCLUSION}

In light of the Wayfair decision, Congress has the choice to act and adopt the requirements set forth in Wayfair, or Congress can continue not to act and leave the choice of how to proceed in the hands of the states. Both approaches have advantages and disadvantages. When these are taken into account, the better option is for Congress to act. If Congress does not act, Congress would leave the decision of how states can collect sales taxes from out-of-state sellers to the states. Each state would have the freedom to adopt their own laws for how to impose a tax on transactions conducted by out-ofstate sellers. This would unduly burden sellers because they would need to remain updated on each state's sales tax laws. In order to maintain consistency throughout the nation, Congress should set a uniform standard for

195. For example, Colorado has a complex system of taxation within its state. With over 300 taxing jurisdictions, Colorado would need to simplify its tax system for out-of-state sellers before it can adopt the requirements set forth by Congress. 
all states to follow. Congress should adopt the requirements set forth in Wayfair, including a uniform nexus requirement, membership in the SSUTA for a simplified registration and remittance system, and a ban on retroactive application of these laws. A Congressional act would not only dissipate the confusion surrounding Wayfair, but it would guide states and sellers in the right direction. 